\title{
(Ethno)mathematics as discourse
}

\author{
(Etno)matemática como discurso
}

Ole Skovsmose*

\begin{abstract}
Interpreting mathematics as a discourse includes three claims: that there are forms of mathematics-reality transitions, that mathematics includes actions, and that mathematics includes a political dimension. Through a discussion of different mathematics-based discursive acts, I will substantiate the discursive interpretation of mathematics. Next, by reconsidering ethnomathematics-based discursive acts, I will argue that also ethnomathematics can be interpreted as a discourse. As in the case of mathematics, ethnomathematics-based discursive acts concern the formation of: possibilities, rationality, structures and artefacts, authority, and overlooking. Finally, I will provide a critical perspective on both mathematics and ethnomathematics through the claim that any kind of action is in need of critical reflections.
\end{abstract}

Keywords: Discursive Acts. Formation of Possibilities. Formation of Rationality. Formation of Structures and Artefacts. Formation of Authority. Formation of Overlooking.

\section{Resumo}

Conceber a matemática como discurso implica considerar três elementos: que existem formas de transição entre a matemática e a realidade; que a matemática inclui ações; e que a matemática tem uma dimensão política. A partir de uma discussão sobre diferentes atos discursivos relacionados à matemática, fundamento a interpretação segundo qual a matemática é um discurso, o que chamo de interpretação discursiva da matemática. Em seguida, reconsiderando atos discursivos sobre etnomatemática, argumento que a etnomatemática também pode ser interpretada como discurso. Assim como no caso da matemática, os atos discursivos sobre a etnomatemática dizem respeito à formação de possibilidades, racionalidade, estruturas e artefatos, autoridade e negligência. Finalmente, exponho a perspectiva crítica sobre matemática e etnomatemática, partindo da afirmação de que qualquer tipo de ação necessita de reflexões críticas.

Palavras-chave: Atos Discursivos. Formação de Possibilidades. Formação da Racionalidade. Formação de Estruturas e Artefatos. Formação de Autoridade. Formação de Ignorância.

\footnotetext{
* Doctor in Mathematics education, Royal Danish School of Educational Studies, Copenhagen, Denmark. Professor Emeritus at Department of Learning and Philosophy, Aalborg University, Nyhavnsgade 14, DK9000 Aalborg, Denmark. Professor Voluntário at Universidade Estadual de São Paulo (UNESP), Rio Claro, SP, Brazil. Endereço para correspondência: Departamento de Matemática, Av. 24-A, 1515, Bela Vista, CEP:13506-700 Rio Claro, SP, Brasil. E-mail: osk@learning.aau.dk.
} 
"Ethnomathematics" can refer to different practices that include mathematics, and often it has referred to practices of marginalised groups. ${ }^{1}$ It can also refer to a research approach, and one can talk about the ethnomathematical research programme. ${ }^{2}$ In the following, I concentrate on ethnomathematics as referring to a variety of practices, although including some remarks about ethnomathematics as a research programme.

Several ethnomathematical studies indicate a duality between ethnomathematics and academic mathematics. On the one hand, academic mathematics is described as a dominant regime of truths that defines standards according to which other ways of thinking about numbers, magnitudes, forms, space, and time turn inadequate, if not simply wrong. Ethnomathematics, on the other hand, is described as integrated in many different everyday practices and as making part of lived-through cultured values. While academic mathematics is characterised mainly through negative terms, ethnomathematics is presented as mainly positive.

One purpose of this paper is to challenge any such duality. I try to show that we do not have to deal with any good-bad dichotomy. However, the purpose of the paper is broader. Thus I will (1) reflect on the use of the notions of mathematics and ethnomathematics; (2) characterise a discursive interpretation of language; (3) formulate the thesis that mathematics is discourse; (4) substantiate this thesis by presenting some mathematics-based discursive acts; (5) reformulate the argument by considering ethnomathematics-based discursive acts; and (6) present a critical perspective on both mathematics and ethnomathematics.

\section{1 "Mathematics" and "ethnomathematics"}

According to the classic referential interpretation of language, the meaning of a notion is the entity to which it refers. This interpretation has been discussed, elaborated, and revised throughout the history of philosophy. Augustine did propose such a general referential interpretation of meaning. And Gottlob Frege, to make a huge jump forward in history,

\footnotetext{
${ }^{1}$ This is, for instance, the use found in Ascher (1991).

${ }^{2}$ For a presentation of an ethnomathematical research programme, see D'Ambrosio (1992, 2006, 2008). Here it is also emphasised that ethnomathematics not only refers to the mathematics of marginalised groups, but can also refer to the mathematics of any cultural groups. See, for instance, also Ribeiro, Domite, and Fereira (Eds.) (2004).
} 
elaborated a referential theory with particular reference to mathematics. ${ }^{3}$ Frege's work established a modern version of Platonism and, in many cases, a referential theory of meaning incorporates features of Platonism.

In Philosophical Investigations, Ludwig Wittgenstein challenged any referential interpretation of language. He made an explicit reference to Augustine, and he was completely familiar with Frege's work. So, Wittgenstein knew what he was up against. Contrary to Frege, he found that it does not make sense to clarify the meaning of a number concept, say " 2 ", by identifying what " 2 " in reality does refer to. Concepts do not have any real reference. Thus, it does not make sense to follow any Platonic approach by clarifying not only mathematical notions but also notions like "beauty", "justice", "truth" by identifying their ideal references. Sure, it is difficult to address questions like: What is a number? What is mathematics, really? What is art? What is a good action? What is knowledge? However, according to Platonism, it is the task of philosophy to address such questions. And even if Platonism is not explicitly assumed, one finds many attempts to address such questions assuming that one is, in fact, looking for a particular answer.

Wittgenstein's point in Philosophical Investigations is that there is nothing particular profound in any questions of the form: What is $\mathrm{X}$ really? The search for the meaning of a notion is not a question of excavating its essence. Concepts have no essence. There is no ideal world of ideas, or references, or essences that is waiting to be discovered. The existence of any such Platonic "eternity" with respect to meaning is a myth.

According to Wittgenstein, we have to look for the meaning of a concept in a quite different way. The meaning has to be located in real-life practices. The meaning of a concept is social and can be associated to the use of the concept. Wittgenstein emphasises this point by introducing the notion of "language game". A concept can make part of different language games and, by exploring such games, one might grasp the meaning of a concept. Some games might be rather similar and demonstrate family resemblances. Language games are cultural products. They can be quite stable during some periods, but change during other periods. Language games can proliferate; they can combine; they are dynamic; and so are the meanings of concepts.

I follow Wittgenstein in this interpretation of meaning. This also applies to a notion like "mathematics". This is not a notion with any proper or principal meaning. "Mathematics" can be part of many different language games. It can refer to different practices and we can

\footnotetext{
${ }^{3}$ See, for instance, Frege $(1967,1978)$.
} 
talk about academic mathematics, pure mathematics, school mathematics, applied mathematics, engineering mathematics, insurance mathematics, mathematics of finance, etc. There is no end to the different possible uses of "mathematics". And as there is a plurality of uses, there is a plurality of meanings of "mathematics".

In a similar way, I use "ethnomathematics" broadly and freely as referring to many different practices. It can refer to shoemakers' mathematics, tailors' mathematics, brick builders' mathematics, sugar cane farmers' mathematics, etc. By following Ubiratan D'Ambrosio's suggestion of using a broad notion of "ethnomathematics", one could, however, also think of engineering mathematics, academic mathematics, insurance mathematics, etc., as examples of ethnomathematics.

In fact, I do not find any particular need of distinguishing between "mathematics" and "ethnomathematics". In the following, I am going to substantiate this claim by showing that a discursive interpretation of language can be applied to both mathematics and ethnomathematics. However, let us proceed step by step.

\section{A discursive interpretation of language}

A general representational interpretation of language is expressed by the picture theory of language as presented by Wittgenstein in Tractatus. The picture theory includes the general claim that language provides a more or less accurate description of reality, and meaning is interpreted in terms of references. Furthermore, Tractatus includes the idea that some languages do the picturing better than other languages. In fact, Wittgenstein talks about the language, and not about languages in plural. According to Wittgenstein, the language adequate for picturing reality is the formal language of mathematics. This language was presented in Principia Mathematica, by Alfred N. Whitehead and Bertrand Russell, but prepared in all details by Frege.

A radical different interpretation of language can be referred to as a discursive interpretation of language. Such an interpretation can be seen as a further development of Wittgenstein's notion of language game. While Tractatus includes one interpretation of language, Philosophical Investigations opens for a very different one. Thus, Wittgenstein is a main figure in two competing interpretations of language.

I will characterise a discursive interpretation of language in terms of three features. The first includes a strict anti-Platonism. We have already indicated what this could mean 
with respect to interpretations of concepts: there are no "real" references that establish their proper meanings. Instead, the meaning of a concept is defined through real-life practices through the use of the concept. More generally, the anti-Platonism that characterises a discursive interpretation of language includes a denial of any attempts to think of the language as providing a representation of reality. A discursive interpretation does not operate with any sharp distinction between language and reality. It opens, instead, different forms of languagereality transitions: reality is discursively constructed while language is formed through reallife practices. So the first feature of a discursive interpretation of language is the recognition of many forms of language-reality transitions.

The second feature of a discursive interpretation of language is the recognition of the action part of language. One finds such a recognition in Wittgenstein's notion of language games, as playing means action. A more explicit formulation of the action part of language is provided by John L. Austin. ${ }^{4}$ He points out that a statement has a locutionary content, an illocutionary force, and a perlocutionary effect. As an example, we can imagine that somebody warns me: Do not to make business with that company! The locutionary content refers to the content of the warning, relating to not making business. The illocutionary force refers to the power of the statements: there is in fact a warning. Finally, the statement has a perlocutionary effect, which refers to the effects that the warning might have: thus, I might feel surprised by the warning. Austin's point is that any statement includes these three features, and one can think of statements including: promises, proposals, excuses, invitations, demands, critique, etc. We do things through language. The speech act theory was further developed by John Searle, whose book, Speech Acts, was published in 1969. From then on, the speech act theory proliferated, and it became generally acknowledged that language includes actions.

The third feature of a discursive interpretation of language is the recognition of the political dimension of language. As an illustration of what this could mean one can listen to the following remark made by Slavoj Žižek: "Language simplifies the designating thing, reducing it to a single feature. It dismembers the thing, destroying its organic unity, treating its parts and properties as autonomous. It inserts the thing into a field of meaning which is ultimately external to it.” (2008, p. 61). Certainly Žižek recognizes the action part of language. However, his formulations are much more radical than Austin's peaceful and innocent examples that were elaborated further in analytical philosophy. Through Austin's

\footnotetext{
${ }^{4}$ See Austin $(1962,1970)$.
} 
philosophy we come to learn about invitations, warnings and promises. But not about, exclusion, stigmatisation, and certainly not about the symbolic violence that is Žižek's topic in the book Violence, from which the quotation above is taken. Symbolic violence represents a big part of the political dimension of language. To recognise this means to recognise that interests, subjectivity, and priorities of any kind may be acted out through language, not only through the explicit statements but as well through the world-view that might be imposed through language.

When one talks about particular interests, subjectivity, and priorities one might assume that it is possible to identify general interest, objectivity, and neutrality. However, the discursive interpretation of language does not make any such assumption. Recognising the political dimension of language also means recognising that, within language, there might not exist any semantic fixed points with reference to which one can judge degrees of interest, subjectivity, and priorities.

\section{Mathematics as discourse}

My proposal is to think of mathematics as a language, and to establish a discursive interpretation of this language. So I suggest that we think of mathematics as discourse. ${ }^{5}$

This means that we neither think of mathematics, nor of mathematical modelling, as a straightforward device for representations. ${ }^{6}$ Mathematics is not a sublime mean for "picturing" reality, as have been suggested in much literature about mathematical modelling. I suggest instead that we recognise the possibility of a broad variety of mathematics-reality transitions; that we think of mathematics as including a dimension of action; and that we acknowledge that mathematics includes a political dimension. Through mathematics one engages in reality: the homo faber is operating with and through mathematics. Through mathematics one can impose certain interests, a particular perspective, a particular worldview. One might as well be able to associate symbolic power as well as a symbolic violence with mathematics.

In the following, I will try to substantiate a discursive interpretation of mathematics. However, before we get into this, let me make a preliminary observation. As indicated at the beginning, the very notion of mathematics cannot be assumed to have any proper and

\footnotetext{
${ }^{5}$ This proposal does not exclude, however, that one can think of mathematics as being other things as well.

${ }^{6}$ This issue I have discussed more carefully in Skovsmose (2012b).
} 
universal meaning. This, however, does not prevent me, and should not prevent us, from using the notion. And, also, using it for making general claims like: mathematics can be seen as discourse. However, making such a general statement does not imply that one tries to say something about the "essence" of mathematics. Making a general statement means that one tries to say something that makes sense for several instances of mathematics. General statements are tentative, they are preliminary, they are suggestions, they can be seen as guesses, and also as bold guesses. Having this in mind, let us proceed.

\section{Mathematics-based discursive acts}

Mathematics operates within a range of social, political, and economic structures in society. Thus, Uwe Gellert and Eva Jablonka (2009, p. 20) emphasises that mathematicsbased decisions operate on many levels: "On the level of national policy, decisions about the distributions of state salaries, pensions, and social benefits rely on mathematical extrapolations of demographical and economic data [...] On the level of interpersonal relations, mathematics-based communication technologies have already changed the habits and styles of private conversations." One could elaborate further on this comment and refer to: administrative procedures, organisational schemes, health care programmes, military operations, etc., as examples of domains where mathematics is put in operation.

I will try to substantiate this general claim by elaborating further the discursive interpretation of mathematics. I will identify some mathematics-based discursive acts by addressing the formation of (1) possibilities, (2) rationality, (3) structures and artefacts, (4) authority, and (5) ways of overlooking. ${ }^{7}$

\subsection{Formation of possibilities}

A characteristic feature of modern technology is the conception of new possibilities for making artefacts of any kind: buildings, bridges, ships, aircrafts, cell phones, etc. One can also think of the formation of, for instance, production processes, management procedures, information processing, schemes for surveillance, etc. For any such construction it is important to provide a blueprint of what to make, and mathematics is essential for this. In all

\footnotetext{
${ }^{7}$ For orther formulations of such acts see, for instance, Skovsmose $(2009,2010)$.
} 
forms of technology, mathematics-based blueprints open new spaces for possibilities. The hectic development taking place in computing and information technology is an example of this.

Naturally, one might consider to what extent mathematics also limits the space of technological possibilities by eliminating what could not be formulated in this very particular language. Also in this sense, mathematics plays a defining role in technological development. The very formation of technological possibilities represents a main example of a mathematics-reality transition.

\subsection{Formation of rationality}

Often in political discussions, it becomes argued that certain economic decisions need to be taken, in order to maintain economic stability. Most often, outputs from a mathematical model have structured such arguments. Models for providing economic forecasting are applied by governments, political parties, research institutions, banks, and companies.

A model of this kind is loaded with information based on statistics. It is as well designed through a huge number of equations, which represent mathematical insight, economic priorities, political perspectives, as well as particular market interests. Altogether, the components of the model establish an economic universe, which becomes used for providing economic forecasting. Certain values become assigned to certain parameters and hypothetical implications become identified by running the model. A broad experimentation with different possible inputs brings about a reading of economic alternatives including their implications. On this basis, one might claim that some "necessary" economic initiatives have been identified. This "necessity", however, is a constructed necessity. It is fabricated by means of the model. The model itself is not any economic reality, but it plays the role of reality. It establishes a symbolic reality as a parallel economic universe. The "necessary" actions are identified within this parallel universe, but applied in real life. In this sense we have to deal with a model-based formation of economic rationality.

A similar formation is found in management and engineering. One finds it when new forms of production become implemented, when possibilities for outsourcing are discussed, and when promotion campaigns are launched. There is a mathematical formation of rationalities in medicine as well as in warfare. Such formations, create actions of profound political significance. We have to deal with power exercised through mathematics. 


\subsection{Formation of artefacts and structures}

If we look at any industrial produced artefact - shoes, cars, computers, plastic bags, etc. - mathematics is crucial for their design and production.

Let us just consider the industrially produced plastic bag that I use when going to buy fruits and vegetables. It is a colourful bag, weaved of plastic stripes. It is very strong and I can put into it as much as I am able to carry. It is an industrially produced bag and I try to imagine the machinery for producing such bags. I remember the section in the Deutsches Museum, in Munich, that shows the history of weaving. Many tools were used before the first spinning machine was constructed in 1764. In fact, it is surprising to see the great homogeneity of tools applied century after century in this production and also to see that the first weaving machine not only represents a discontinuity in this development, by being a machine, but also a big homogeneity by applying the usual tools. The machines, however, were rapidly developed. Machine power was added and the weaving machines took tremendous dimensions. Later, computational techniques were added and the automatisation became tremendously sophisticated. My plastic bag has been produced by machinery of this kind - machinery which represent a complex mathematics-based development.

However, not only artefacts, but also the very structures of production, become formed through mathematics. Let me refer to one such specific feature of production, namely robotting. ${ }^{8}$ Some initial steps in the configuration of workers as "robots" were presented by Frederick W. Taylor, in The Principles of Scientific Management, published in 1911. Here, he describes how the worker, Schmidt, became subjected to the principles of scientific management. Schmidt was loading pig iron onto a railway wagon and it was observed what an average worker was loading per day. Taylor and his staff had, however, analysed the working process in all its atomic parts and got to the conclusion that a new way of organising the whole process would more than triple the loading efficiency. A new working algorithm, prescribing what to do and when to do it, became presented to Schmidt. This way he became configured as a robot.

Taking a look into any industrial production today, one finds human robots and proper robots united in complex processes of production. The distinction between what is completed by human beings and what is done by machines is not easy to maintain. In fact, in terms of

\footnotetext{
${ }^{8}$ For a discussion of robotting, see Skovesmose (2012a).
} 
efficiency it becomes irrelevant to make any such distinction, as it is the combined machinery that is optimised. The whole configuration of production could only take place through an extensive use of mathematical modelling, including mathematics-based cost-benefit analyses. This way, mathematics defines the whole formation of structures of production. This also applies to the production of my colourful bag.

\subsection{Formation of authority}

Mathematics-based discursive acts include a reconfiguration of authority. Claims expressed in numbers more easily turn powerful. This is an example of symbolic power exercised by politicians, governments, and institutions with access to mathematical models.

However, authority is not only formed through the power of argument, it is also established through the power of controlling. As a particular example, one can consider the technology of surveillance. ${ }^{9}$ Surveillance means observing in order to control what is taking place. However, efficient surveillance also means remembering or registering what has been observed.

Surveillance is crucial for making a population governable. One can register names of people; their actions, and in particular their criminal acts. You can register people's income, debt, fortune, all kind of important information for determining and controlling tax payment. One can register people's health conditions, and try to make medical treatment more effective. One can register opinions and political priorities and try to make political campaigns more powerful. You can register students' performances, and on this basis, try to establish efficiency with respect to the distribution of students in streams of further education; and in the end provide a formation of a more productive coming work force. One can register the workers' performances, and try to optimise production processes.

All such forms of registering are mathematics-based. They are crucial for making a population governable. It makes part of the formation of authority.

\subsection{Formation of overlooking}

Through mathematics one can see many things. At the same time, mathematics representsthe systematics of ignoring and overlooking. As an example, one can think of

\footnotetext{
${ }^{9}$ For a more detailed discussion or this example, see Skovsmose (2012a).
} 
mathematics-based scientific managements. As just referred to, this management imposes a mathematical perspective on the process of production. One see production as a mechanical process which one could try to optimise; and workers become configured as elements in this mechanical process.

This configuration also means that many features of being a worker become ignored. That the worker has a family, has responsibilities, and has personal interests and priorities, do not make part of the mathematic-based representation of the worker as an element in the production process. In general, mathematics does not represent human beings as being human. Instead, mathematics facilitates a mechanical perspective being on nature, economic issues, socio-political affairs, or on human beings. In all such cases, mathematics operates as a means for both seeing and overlooking.

\section{Ethnomathematics-based discursive acts}

The previous section dealt with mathematics-based discursive acts in terms of formation of possibilities, rationality, artefacts and structures, authority, and overlooking. I tried to explore these acts with reference to examples of what broadly could be referred to as engineering mathematics. This way, I have tried to illustrate that mathematics-based acts transgress any language-reality dichotomy, that they forms actions; and that they include a political dimension. In other words, I have tried to show that a discursive interpretation of mathematics makes sense.

But what about ethnomathematics? I will try to illustrate that it makes good sense to talk about ethnomathematics-based discursive acts. Through such acts, one also forms possibilities, rationality, structures and artefacts, authority, as well as ways of overlooking.

\subsection{Formation of possibilities}

As an example of formation of possibilities, one can think of travelling and navigation. If we consider the period of the so-called big discoveries, one constructed more or less reliable maps; and before any mapping could be done, one tried to identify a route or a direction. One could go West. But what could that mean staying in a boat in the middle of the ocean? Many tools for navigation were developed, not only the compass but also the sextant, besides a range of calculation devices. 
We can go further back in time and think of the Vikings who reached Iceland, then Greenland, and finally America. They navigated, although without compass, but certainly they used a range of techniques and tools for reading the stars. Thus, the firmament of stars was a rather stable, although rotating, dome above the all too capricious ocean. We can also consider the crossing of the ocean performed by the Polynesians. They populated the thousands of islands in the Pacific and demonstrated a most remarkable capacity of navigating.

The mathematics involved in navigation provides a range of examples of ethnomathematics, and one can think of navigation as an example of ethnomathematics-based discursive acts. ${ }^{10}$ Navigation does not include any sharp distinction between mathematics and reality. Quite contrary, navigation represents a complex mix of interpreting and doing something; it represents as well a mathematics-based formation of possibilities. Similar remarks apply as well to any form of navigation today, including the most advanced systems operating in space missions, as well as in GPS used, for instance, when tourists try to find their way around.

\subsection{Formation of rationalities}

Let us consider procedures for dividing. Making a division is a social process. It takes place in families, communities, in larger contexts. It is a process that becomes elaborated into extreme complexity in tax systems and in public welfare systems. Naturally, it is an open question what to consider as a fair division. One can think of the mathematical algorithm for division as a formal suggestion, although very simplistic, for what fairness could mean.

Let me refer to an example that was told to me by a researcher in ethnomathematics: "Members of a group of Indians were presented with the following question. Three men were out fishing together. They caught a total of 36 fishes. How many did each of them get? The Indians looked at each other and asked: What kind of fish was it?"

To mathematics teachers this answer might sound funny. But it can instead be seen as demonstrating the complexity of the notion of "fair division". This notion is far from always

\footnotetext{
${ }^{10}$ For an overview of "Pacific ethnomathematics" see Goetzfridt (2007).
} 
grasped by mathematical division. For instance, the division could concern very small fishes that better had to be prepared all together. Or big and tasty fishes that need to be distributed according to the size of the families. The mathematical algorithm of division provides one interpretation of what a fair division could mean, but just one interpretation that might overlook a range of parameters that also need to be considered.

One can see several ethnomathematical approaches as attempts to provide rationales for making fair divisions. As an example, you can think of techniques for measuring lands, as for instance developed in sugarcane farming. ${ }^{11}$ One aim of this measuring is to estimate what could be a fair payment in total; another aim could be to make a fair division among the workers. And certainly, at any time one could raise the socio-political question about what a "fair division" could mean.

\subsection{Formation of artefacts and structures}

Many ethnomathematical studies have addressed the construction of artefacts. ${ }^{12}$ As an example, think of basket weaving. Through a range of studies, Paulus Gerdes has demonstrated that mathematical competences are represented in weaving practices. In his book Otthava, he analyses such practices in the Makhuwa culture, located in the Northeast part of Mozambique. ${ }^{13}$ Beyond the weaving of baskets and handbags, Gerdes investigates the weaving of hats, fish traps, containers, trays, mats, and several other artefacts as well. He tries to identify the kind of knowledge that becomes acted out through weaving practices, for instance, concerning symmetries, spirals, and cylinders. Thus, Gerdes provides a profound study of the different layers of tacit knowledge that forms such practices, and among such layers he finds mathematics.

Such research approaches, however, have been object for a heated discussion. Do we, in fact, have to deal with any application of mathematics? It has been claimed that we, instead, have to deal with a projection of mathematical ideas into the weaving process. The weaving process includes a range of procedures and competences that form a complex amount of tacit knowledge. But it is only the outsider, the onlooker, the mathematician, who identifies the mathematics of this tacit knowledge. Thus, it has been claimed that the ethnomathematics

\footnotetext{
${ }^{11}$ See, for instance, Abreu (1993).

12 See, for instance, Costa, Catarino and Nacimento (2008a, 2008b); Giongo (2004); and Souza, PALHARES and Saramento (2008).

${ }^{13}$ See Gerdes (2012). See also Gerdes (2008); and Vieira, Palhares and Sarmento (2008).
} 
included in the weaving of baskets is an invention; it is an external reconstruction. The ethnomathematics in such practices has been falsely added.

Let us again consider my industrialised produced plastic bag. Does it include mathematics? Well, in the sense that enormous amounts of mathematics are put in operation along the development of weaving machines. Mathematics is part of the fabrication of the machines, in the organization of the production process, and in the computational automatisation of it all. In this sense, my plastic bag is rich of mathematics.

Who is aware of this mathematics? Well, I do not think of any such thing when I use the bags. This is no surprise. The operators involved in the production, then? Well, they are operating the machines. They are observing that everything works properly. They are checking the computer screens. I would, however, be surprised if the operators find that they are doing mathematics. What, then, about the engineers who have configured the machines for this particular production? They might have used mathematics explicitly. However, basically, the engineering mathematics involved in the industrial production of plastic bags does not emerge in the situation. It stays as a tacit knowledge inscribed in the machinery in operation. This observation relates to processes of demathematisation, which are accompanying the mathematisation of society. ${ }^{14}$

Naturally, one may claim that this engineering mathematics has been explicit at least at some stages in bag-weaving process, while the basket-weaving mathematics has been imposed on the situation. However, I do not find the difference between basket-weaving mathematics and bag-weaving mathematics to be that crucial. In both cases, we have to deal with a mathematics that forms processes of production.

\subsection{Formation of authority}

Authority can be exercised through procedures and regulations. We can think of procedures for taxation. The identification of the amount tax to be paid by a person is far from just a descriptive statement, it is an act, it is a political act, and it represents power and authority.

More generally, authority becomes exercised through claims about how to do things. As an example one can think of the definition of procedures for production. We find examples

\footnotetext{
${ }^{14}$ For a discussion of mathematisation and demathematisation see Gellert and Jablonka (2009); and Jablonka and Gellert (2007).
} 
in modern and industrialised forms of production, but one can also think of many other examples. Let me just refer to one example presented by Aldo Parra Sánchez (2012), who for a period stayed together with groups of Indians in the Andes, in Colombia. In particular, he followed the plantation of corn, which during centuries has been the principal food ingredient in this region.

The plantation and cultivation of corn is emerged in routines and rituals. For instance, corn has to be planted, not in long and parallel rows, but in a huge spiral covering the whole field. The straight lines that we are so used to see in industrialised farming are machine made, while the spiral is hand made. But there might be more into the spiral than just handcraft. This way of organising the plantation can be interpreted as an expression of an understanding of what it means to engage with nature. The spiral is an expression of tradition and culture, combined into certain ethnomathematics.

One can see the organisation of production, as initiated by scientific management, as an expression of particular metaphysics relating to exploitation. One can as well see the organisation of the cultivation of corn as an expression of a metaphysics, although a quite different one. Different as they are, both cases can be read as examples of authority formation. In the case of the corn production, we have to deal with an authority rooted in tradition, culture, and metaphysical ideas. And the ethnomathematical expression of this authority provides a pattern for how to do things. In the case of industrial production, we also find an authority - here expressed through standards and algorithms for production, steered by criteria for maximising profit.

\subsection{Formation of overlooking}

Ethnomathematical studies have concentrated on showing what one should come to see and grasp through ethnomathematical insights and techniques, and maybe first of all: what one should be able to do.

There are not many ethnomathematical studies that concentrate on revealing what an ethnomathematical perspective on a certain phenomenon might ignore and overlook. In fact, now thinking about it, none such studies come to mind. Anyway, I see ethnomathematics, as mathematics in general, as forming not only what one sees, but also what one overlooks.

This issue, however, is in need of being explored much further. And there are many issues that one could consider. House building: Are there any possibilities for construction 
that tend to be ignored, due to the ethnomathematical outlook? Basket weaving: It has been carefully studied in what sense weaving techniques condense ethnomathematical insight and competence. Are there, however, any such insight that represents limitations and obstructions for the weaving? Health care: Are there, due to the ethnomathematical perspectives, possibilities that have been ignored with respect to the potentials of the natural medicine available? Sugar cane farming: It has been carefully studied how areas have been measured and salary for field work has been calculated. Are there elements of such calculations that may serve the workers' interest, or serve the employers' interests?

I find it important, in order to provide a more complete picture of techniques that are rooted in ethnomathematics, that the possibilities of ignoring and overlooking also become broadly explored.

\section{Acts can have all kind of qualities}

I have tried to show that discursive acts can be associated to both mathematics and ethnomathematics. In both, cases we find formations of possibilities, rationality, structures and artefacts, authority, and overlooking. Considering particular examples of such discursive acts, we find that they include a transgression of any mathematics-reality distinction, that they include actions, and that they can be political. ${ }^{15}$

Both mathematics and ethnomathematics operate through discursive acts, and such acts, like any other kind of act, can have any kind of qualities. They might be efficient, misguiding, expensive, risky, authoritative, benevolent, suppressive, dubious, etc. This means that both mathematics and ethnomathematics are in need of equally profound critical approaches. A general critique of mathematics has been formulated, for instance, through the discussion of mathematics in action and the formatting power of mathematics. However, it is equally important to provide careful critique of ethnomathematics in action and the formatting power of ethnomathematics. As a consequence, I do not think it makes sense to elaborate on any duality between, say, ethnomathematics and academic mathematics, as referred to in the introduction. And certainly it does not make sense to try to associate a range of positive qualities to ethnomathematics leaving dubious qualities for academic mathematics.

\footnotetext{
${ }^{15}$ Many studies address explicitly the political dimension of ethnomathematics. See, for instance, Knijnik (1996, 2008), and Knijnik, Wanderer, and Oliveira (Eds.) (2004).
} 
Let me now return to the very distinction between "mathematics" and "ethnomathematics". I find it makes sense to provide a discursive interpretation of ethnomathematics as well as of mathematics in general. As a consequence, I do not see any particular reason for maintaining any distinction between mathematics and ethnomathematics. In fact, I prefer to talk about mathematics, keeping in mind my initial observation that "mathematics" is an open concept without any Platonic kernel. We have to deal with a multitude of mathematics and one can talk about the mathematics of making plastic bags as well as the mathematics of basket weaving. So, I do not want to make any distinction between practices including mathematics and practices including ethnomathematics. ${ }^{16}$

Let me conclude with a remark about ethnomathematics as a research programme. One can consider ethnomathematics a way of looking at mathematics in any of its many cultural instantiations. ${ }^{17}$ It is a way of addressing the social dimensions of mathematics, whatever kind of mathematics we have to deal with. Being so, I find the ethnomathematical research programme to be crucial. It might open for a critical perspective on mathematics in any kind of practice.

\section{Acknowledgements}

I want to thank Denival Biotto Filho, Renato Marcone, Raquel Milani, Miriam Godoy Penteado, Aldo Parra Sánchez, and Guilherme Henrique Gomes da Silva, for suggestions and critical comments. This article will be published as well in C. Bergsten and B. Sriraman (Eds.), Refractions of Mathematics Education Festschrift for Eva Jablonka. Charlotte, North Carolina, USA: Information Age Publishing. I thank the editors for kind permission to do so.

\section{References}

ABREU, G. The Relationship between home and school mathematics in a farming community in rural Brazil. Doctoral dissertation. Cambridge: Cambridge University, 1993.

\footnotetext{
${ }^{16}$ Finally I got to this conclusion. However, I am far from the first getting there. Thus the title of Costa, Catarino and Nascimento (2008a, 2008b) are "Tanoeiros em Trás-os-Montes e Alto Douro: Saberes (etno)matemáticos" and. "Latoeiros em Trás-os-Montes e Alto Douro: Saberes (etno)matemáticos". Like in my title they talk about (ethno)mathematics.

${ }^{17}$ See, for instance, Fernandéz (2004).
} 
ASCHER, M. Ethnomathematics: A multicultural view of mathematical ideas. Boca Raton, London, New York, Washington, D.C.: Chapman and Hall/CRC, 1991.

AUSTIN, J. L. How to do things with words. Oxford: Oxford University Press, 1962

AUSTIN, J. L. Philosophical papers. 2nd ed. Edited by J. O. Urmson and G. J. Warnock. Oxford: Oxford University Press, 1970.

COSTA, C.; CATARINO, P. A.; NACIMENTO, M. M. Tanoeiros em Trás-os-Montes e Alto Douro: Saberes (etno)matemáticos. In: PALHARES, P. (Ed.). Etnomatemática: Um olhar sobre a diversidade cultural e a aprendizagem matemática. Ribeirão: Edições Húmus, 2008a. p.193-233.

COSTA, C.; CATARINO, P. A.; NACIMENTO, M. M. Latoeiros em Trás-os-Montes e Alto Douro: Saberes (etno)matemáticos. In: P. PALHARES (Ed.). Etnomatemática: Um olhar sobre a diversidade cultural e a aprendizagem matemática. Ribeirão: Edições Húmus, 2008b. p. 235-264.

D'AMBROSIO, U. Ethnomathematics: A research programme on the history and philosophy of mathematics with pedagogical implications. Notices of the American Mathematics Society, v. 39, n. 10, p. 1183-1185. December 1992.

D'AMBROSIO, U. Ethnomathematics: Link between traditions and modernity. Rotterdam: Sense Publishers, 2006.

D’AMBROSIO, U. Globalização, educação multicultural e o programa etnomatemática. In: P. PALHARES (Ed.). Etnomatemática: Um olhar sobre a diversidade cultural e a aprendizagem matemática. Ribeirão: Edições Húmus, 2008, p. 23- 46.

FERNÁNDEZ, E. L. As matemáticas da tribo europeia: Um estúdio de caso. In: G. Knijnik; F. Wanderer; Oliveira, C. J. (Ed.). Etnomatemática, currículo a formação de professores. Santa Cruz do sul: EDUNISC. 2004. p. 124-138.

FREGE, G. Begriffsschrift, a formal language, modeled upon that of arithmetic, for pure thought. In: J. v. Heijenoort (Ed.). From Frege to Gödel: A source book in mathematical logic, 1879-1931. Cambridge (USA): Harvard University Press, 1967, p 1-82. (Original German edition 1879.)

FREGE, G. The foundations of arithmetic/Die Grundlagen der Arithmetik. German text with an English translation by J. L. Austin. Oxford: Blackwell, 1978, (Original German edition 1884.)

GELLERT, U.; JABLONKA, E. The demathematising effect of technology. In: P. Ernest; B. Greer; B. Sriraman (Ed.). Critical issues in mathematics education. Charlotte, NC, USA: Information Age Publishing, 2009, p.19-24.

GERDES, P. Explorando poliedros do Nordeste de Moçambique. In: P. Palharas (Ed.).

Etnomatemática: Um olhar sobre a diversidade cultural e a aprendizagem matemática. Ribeirão: Edições Húmus, 2008, p. 317-359.

GERDES, P. Otthava: Making baskets and doing geometry in the Makhuwa culture in the Northeast of Mozambique. Morrisville North Carolina: Lulu.com, 2012.

GIONGO, L. M. Etnomatemática e práticas de produção de calcados. In: G. Knijnik, F. Wanderer and C. J. Oliveira (Ed.). Etnomatemática, currículo a formação de professores. Santa Cruz do sul: EDUNISC, 2004, p. 203-218. 
GOETZFRIDT, N. J. Pacific ethnomathematics: A bibliographic study. Honolulu: University of Hawaii Press, 2007.

JABLONKA, E.; GELLERT, U. Mathematisation - demathematisation. In: U. Gellert; E. Jablonka (Ed.). Mathematization and de-mathematization: social, philosophical and educational ramifications. Rotterdam: Sense Publishers, 2007. p. 1-18.

KNIJNIK. G. Exclução e resistência: Educação matemática e legitimidade cultural. Porto Alegre: Artes Médicas, 1996.

KNIJNIK. G. Educação matemática e diversidade cultural: Matemática camponesa na luta pela terra. In: PALHARES, P. (Ed.). Etnomatemática: Um olhar sobre a diversidade cultural e a aprendizagem matemática. Ribeirão: Edições Húmus, 2008. p. 131-156.

KNIJNIK, G., WANDERER, F.; OLIVEIRA, C. J. (Eds.). Etnomatemática, currículo a formação de professores. Santa Cruz do sul: EDUNISC, 2004.

PARRA SÁNCHEZ, A. I. Etnomatemática e educação própria. 2011. 118 f. Dissertação (Mestrado em Educação Matemática) - Instituto de Geociências e Ciências Exatas, Universidade Estadual Paulista, Rio Claro, 2012.

RIBEIRO, J. P. M.; DOMITE M. do C. S.; FEREIRA R. (Ed.). Etnomatemática: Papel, valor e significado. São Paulo: Zouk, 2004.

SEARLE, J. Speech acts. Cambridge: Cambridge University Press, 1969.

SKOVSMOSE, O. In doubt: About language, mathematics, knowledge and life-world. Rotterdam: Sense Publishers, 2009.

SKOVSMOSE, O. Symbolic power and mathematics. In: BHATIA, R. (Ed.). Proceedings of the International Congress of Mathematicians. vol. 1. Hyderabad, India: Hindustan Book Agency, 2010. p. 690-705.

SKOVSMOSE, O. Symbolic power, robotting, and surveilling. Educational Studies in Mathematics. v. 80, n. 1, p. 119-132, February 2012a.

SKOVSMOSE, O. Mathematics as discourse. Bolema, v. 26, n. 43, p. 1-18, ago. 2012 b.

SOUSA, F.; PALHARES, P.; SARMENTO, M. Calafantes na Baía de Câmara de Lobos. In: P. PALHARES (Ed.). Etnomatemática: Um olhar sobre a diversidade cultural e a aprendizagem matemática. Ribeirão: Edições Húmus, 2008. p. 157-191.

TAYLOR, F. W. The principles of scientific management. New York: Cosimo Classics, 2006. (First published in 1911.)

VIERIRA, L.; PALHARES, P.; SARMENTO, M. Etnomatemática: Estudo de elementos geométricos presentes na cestaria. In: P. PALHARES (Ed.). Etnomatemática: Um olhar sobre a diversidade cultural e a aprendizagem matemática. Ribeirão: Edições Húmus, 2008. p. 291-315.

WHITEHEAD, A. N.; RUSSELL, B. Principia mathematica I-III. Cambridge: Cambridge University Press, 1910-1913.

WITTEGENSTEIN, L. Tractatus logico-philosophicus. German text with an English. Translation: C. K. Ogden, Introduction by Bertrand Russell. London: Routledge, 1992. (First German edition 1921). 
WITTEGENSTEIN, L. Philosophical investigations. Translation: G. E. M. Anscombe, 2nd Ed. Oxford: Basil Blackwell, 1958. (First published 1953).

ŽIŽEK, S. Violence. New York: Picador, 2008.

Submetido em Dezembro de 2013. Aprovado em Abril de 2014. 